\title{
SISTEM PENDUKUNG KEPUTUSAN \\ ROTASI POSISI DUDUK SISWA DALAM KELAS (STUDI KASUS SDN PURWODADI 1 MALANG)
}

\author{
Inggrid Yanuar Risca Pratiwi ${ }^{1}$, Ekojono², Rudy Ariyanto ${ }^{3}$ \\ ${ }^{1,2}$ Program Studi Teknik Informatika, Jurusan Teknologi Informasi, Politeknik Negeri Malang \\ Jalan Soekarno Hatta No. 9 Malang 65141, Jawa Timur, Indonesia \\ ${ }^{1}$ grid94@gmail.com, ${ }^{2}$ ekojono@ polinema.ac.id, ${ }^{3}$ ariyantorudy@ gmail.com
}

\begin{abstract}
Abstrak
Selama ini rotasi posisi duduk siswa dalam kelas dibebaskan oleh walikelas. Ada siswa yang memakai kacamata duduk di belakang, siswa yang pandai duduk di depan, siswa yang pendek duduk di belakang dan adapula orang tua siswa yang menitipkan anaknya kepada walikelas untuk menempatkan duduk di depan. Hal ini menimbulkan posisi duduk yang tidak merata yang seharusnya mendapatkan posisi duduk yang sebenarnya tetapi mendapatkan posisi yang sebaliknya.

Dengan adanya permasalahan ini diperlukan suatu sistem pendukung keputusan rotasi posisi duduk siswa dalam kelas di SDN Purwodadi 1 Malang menggunakan metode SAW (Simple Additive Weighting) agar dapat membantu walikelas untuk mendukung keputusan rotasi posisi duduk siswa dalam kelas yang seimbang dan optimal agar para siswa mendapatkan posisi duduk yang tepat sehingga dapat mempengaruhi proses belajar mengajar yang baik serta meningkatkan nilai rata - rata siswa dalam kelas.

Sistem Pendukung keputusan rotasi posisi duduk siswa dalam kelas ini dapat memberikan penilaian pendukung keputusan rotasi posisi duduk siswa dalam kelas dengan menggunakan metode SAW berupa rangking dan selanjutnya diimplementasikan pada pola posisi duduk siswa serta dapat membantu walikelas untuk mendukung keputusan rotasi posisi duduk siswa dalam kelas berdasarkan empat kriteria yaitu sikap siswa, penggunaan kacamata pada siswa, nilai siswa dan tinggi badan siswa terbukti berdasarkan hasil kuesioner yang diisi oleh walikelas dengan tingkat akurasi sebesar $82 \%$.
\end{abstract}

Kata Kunci : Sistem Pendukung Keputusan, Rotasi Posisi Duduk Siswa, SAW

\section{Pendahuluan}

Seorang guru harus memiliki satu konsep dalam strategi belajar mengajar siswa, konsep tersebut adalah melakukan rotasi posisi duduk siswa dalam kelas. Ada suatu indikasi jika siswa dibiarkan begitu saja memilih sendiri tempat duduknya, maka bagi siswa yang motivasi belajarnya kurang baik tentu akan memilih tempat duduk di bangku sudut paling belakang. Rotasi posisi duduk dapat mempengaruhi prestasi siswa.

Selama ini rotasi posisi duduk siswa dalam kelas dibebaskan oleh para walikelas tidak ada aturan tertentu. Dimana ada siswa yang memakai kacamata duduk di belakang, siswa yang pandai duduk di depan, siswa yang pendek duduk di belakang dan adapula orang tua siswa yang menitipkan anaknya kepada walikelas untuk menempatkan duduk di depan. Hal ini menimbulkan posisi duduk yang tidak merata pada siswa yang seharusnya mendapatkan posisi yang seharusnya tetapi mendapatkan keadaaan yang sebaliknya.
Dengan adanya permasalahan ini diperlukan suatu sistem pendukung keputusan rotasi posisi duduk siswa dalam kelas di SDN Purwodadi 1 Malang menggunakan metode SAW (Simple Additive Weigthing) agar dapat membantu walikelas untuk mendukung keputusan rotasi posisi duduk siswa dalam kelas yang seimbang dan optimal agar para siswa mendapatkan posisi duduk yang tepat sehingga dapat mempengaruhi proses belajar mengajar yang baik serta meningkatkan nilai rata rata siswa dalam kelas.

\section{Tinjauan Pustaka}

\subsection{Sistem Pendukung Keputusan}

Sistem Pendukung Keputusan bertujuan untuk menyediakan informasi, membimbing, memberikan prediksi serta mengarahkan kepada pengguna informasi agar dapat melakukan pengambilan keputusan dengan lebih baik. Sistem pendukung keputusan tidak dimaksudkan untuk mengotomatosasi pengembalian keputusan, tetapi memberikan perangkat interaktif yang 
memungkinkan pengambilan keputusan untuk melakukan berbagai analisis menggunakan model model yang tersedia. (Kusrini, 2007).

\subsection{Rotasi Posisi Duduk Siswa}

Tempat duduk dapat mempengaruhi siswa dalam belajar. Dalam mengatur tempat duduk sebernarnya akan berhubungan dengan permasalahan siswa sebagai individu dengan perbedaan pada aspek biologis, intelektual, dan psikologis (Djamarah \& Aswan, 2013).

Pengaturan tempat duduk siswa dapat mempengaruhi peserta didik dalam mencapai keberhasilannya. Perubahan formasi tempat duduk memiliki banyak manfaat yaitu menghindari kejenuhan peserta didik, menjadikan fokus belajar tetap terjaga, meningkatkan konsentrasi belajar, memudahkan guru maupun siswa untuk bergerak dan berinteraksi pada saat kegiatan - belajar mengajar berlangsung (Harsanto dalam Dirgantoro, 2012).

Penataan rotasi duduk adalah salah satu upaya yang dilakukan oleh guru dalam mengelola kelas. Karena pengelolaan kelas yang efektif akan menentukan hasil pembelajaran yang dicapai. Dengan penataan tempat duduk yang baik maka diharapkan akan menciptakan kondisi belajar yang kondusif, dan juga menyenangkan bagi siswa.

Menurut Ronal L. Partin (2012) mengemukakan posisi tempat duduk siswa memang mempunyai pengaruh terhadap prestasinya di kelas. Dimana siswa yang duduk di bangku depan mau tidak mau harus memperhatikan guru yang sedang mengajar. Sehingga secara tidak langsung siswa tersebut akan mudah menyerap materi. Berbeda dengan siswa yang duduk di belakang, mereka memiliki kesempatan lebih banyak untuk tidak memperhatikan guru dalam proses pembelajaran.

\subsection{Metode SAW (Simple Additive Weighting)}

SAW Merupakan metode penjumlahan terbobot. Konsep dasar metode SAW adalah mencari penjumlahan terbobot dari rating kinerja pada setiap alternatif pada semua kriteria (Kusumadewi, 2006).

Metode SAW membutuhkan proses normalisasi matrik keputusan $(\mathrm{X})$ ke suatu skala yang dapat diperbandingkan dengan semua rating alternative yang ada. Metode SAW mengenal adanya dua atribut yaitu kriteria keuntungan (benefit) dan kriteria biaya (cost).

Adapun langkah penyelesaian dengan menggunakan metode SAW adalah :

1. Menentukan alternative, yaitu $A_{i}$.

2. Menentukan kriteria yang akan dijadikan acuan dalam pengambilan keputusan, yaitu $\mathrm{C}_{\mathrm{j}}$.

3. Memberikan nilai rating kecocokan setiap alternatif pada setiap kriteria.
4. Menentukan bobot preferensi atau tingkat kepentingan $(\mathrm{W})$ setiap kriteria. $\mathrm{W}=\left[\mathrm{W}_{1}, \mathrm{~W}_{2}\right.$, $\mathrm{W}_{3}, \ldots \mathrm{W}_{\mathrm{j}}$ ]

5. Membuat tabel rating kecocokan dari setiap alternatif pada setiap kriteria.

6. Membuat matrik keputusan (X) yang dibentuk dari table rating kecocokan dari setaip aternatif pada setiap kriteria. Nilai $X$ setiap alternative $\left(\mathrm{A}_{\mathrm{i}}\right)$ pada setiap kriteria $\left(\mathrm{C}_{\mathrm{j}}\right)$ yang sudah ditentukan, dimana $\mathrm{i}=1,2, \ldots \mathrm{m}$ dan $\mathrm{j}=1,2, \ldots \mathrm{n}$.

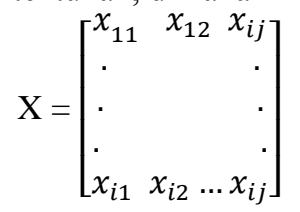

7. Melakukan normalisasi matrik keputusan dengan cara menghitung nilai rating kinerja ternormalisasi $\left(\mathrm{r}_{\mathrm{ij}}\right)$ dari alternative $\mathrm{A}_{\mathrm{i}}$ pada Kriteria $\mathrm{C}_{\mathrm{j}}$.

$$
\mathrm{r}_{\mathrm{ij}}=\left\{\begin{array}{l}
\frac{x_{i j}}{\operatorname{Max}_{i}\left(x_{i j}\right)} \\
\frac{\operatorname{Min}_{i}\left(x_{i j}\right)}{x_{i j}}
\end{array}\right.
$$

Dimana :

$r_{i j} \quad=$ Rating kinerja ternormalisasi

$\operatorname{Max}_{i}=$ Nilai maksimum dari setiap baris dan kolom

Min $_{i}=$ Nilai minimum dari setiap baris dan kolom

$x_{i j}=$ Baris dan kolom dari matriks

Keterangan :

- Kriteria keuntungan (benefit) apabila nilai memberikan keuntungan bagi pengambil keputusan, sebaliknya kriteria biaya (cost) apabila menimbulkan biaya bagi pengambil keputusan.

8. Hasil dari nilai rating kinerja ternormalisasi $\left(\mathrm{r}_{\mathrm{ij}}\right)$ membentuk matrik ternormalisasi (R)

$$
\mathrm{R}=\left[\begin{array}{lrrr}
r_{11} & r_{12} & \ldots & r_{1 j} \\
\cdot & & & \cdot \\
\cdot & & & \cdot \\
\cdot & & & \cdot \\
r_{i 1} & r_{i 2} & \ldots & r_{i j}
\end{array}\right]
$$

9. Hasil akhir nilai preferensi (Vij) diperoleh dari penjumlahan dari perkalian elemen baris matrik ternormalisasi (R) dengan bobot prefernsi (W) yang bersesuaian elemen kolom matrik $(\mathrm{W})$.

$$
\mathrm{V}_{\mathrm{i}}=\sum_{j=1}^{n} W_{j} r_{i j}
$$

Dimana :

$\mathrm{Vi}=$ Nilai akhir dari alternative

$\mathrm{Wi} \quad=$ Bobot yang telah ditentukan

$\mathrm{r}_{\mathrm{ij}} \quad=$ Normalisasi mariks

Hasil perhitungan nilai $\mathrm{V}_{\mathrm{i}}$ yang lebih besar mengindikasikan bahwa alternatif $\mathrm{A}_{\mathrm{i}}$ merupakan alternatif terbaik (Kusumadewi, 2006). 


\subsection{Distribusi Frekuensi}

Distribusi frekuensi adalah penyusunan suatu data mulai dari terkecil sampai terbesar yang membagi banyaknya data ke dalam beberapa kelas. Kegunaan distribusi frekuensi adalah untuk memudahkan data dalam penyajian, mudah dipahami dan mudah dibaca sebagai bahan informasi.

Teknik pembuatan distribusi frekuensi :

a) Mengurutkan data dari terkecil sampai terbesar.

b) Menghitung jarak atau rentangan ( $R$ )

Rumus : $\mathrm{R}=$ data tertinggi - data terkecil. (5)

c) Menghitung jumlah kelas dengan Sturges :

Rumus : $\mathrm{K}=1+3.3 \log \mathrm{n}$

$$
\mathrm{n}=\text { jumlah data }
$$

d) Menghitung panjang kelas interval (P)

$$
\text { Rumus : } \quad \frac{\text { Rentangan }(\mathrm{R})}{\text { Jumlah Kelas }(\mathrm{K})}
$$

e) Menentukan batas data terkecil, dilanjutkan menghitung kelas interval, caranya menjumlahkan ujung bawah kelas ditambah panjang kelas (P) dan hasilnya dikurangi 1 sampai pada batas akhir.

f) Membuat tabel sementara (tabulasi data) dengan cara dihitung satu demi satu yang sesuai dengan urutan interval kelas.

g) Membuat tabel distribusi frekuensi dengan cara memindahkan semua angka frekuensi (f).

\section{Analisa dan Perancangan}

\subsection{Rancangan Arsitektur SPK Rotasi Posisi \\ Duduk Siswa dalam Kelas}

Rancangan arsitektur digunakan untuk membangun SPK rotasi posisi duduk siswa dalam kelas yang mampu mendukung keputusan siswa dirotasi posisi duduknya. Arsitektur sistem pendukung keputusan dapat dilihat pada gambar 1 komponen DSS yang digunakan pada sistem.

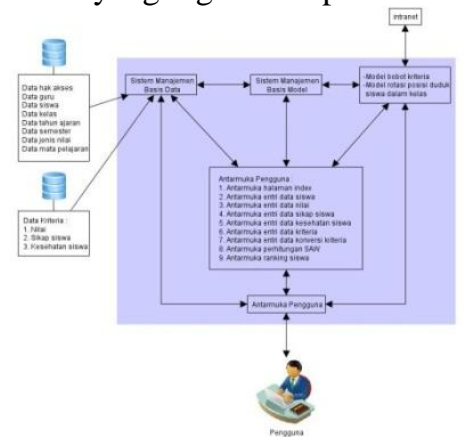

Gambar 1 Arsitektur SPK Rotasi Posisi Duduk

\subsection{Use Case Diagram}

Pada tahap ini dilakukan pemodelan aktivitas aktor dengan sistem untuk mengetahui fungsi fungsi yang ada di dalamnya. Sistem ini memiliki 2 aktor yaitu tata usaha dan walikelas. Gambar 3.2 menggambarkan aktor walikelas dan Gambar 3.3 menggambarkan aktor tata usaha.

\subsubsection{Aktor Wali Kelas}

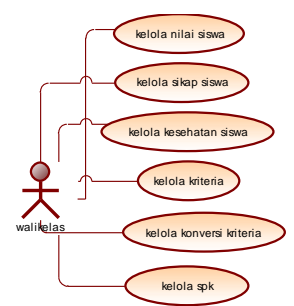

Gambar 2 Usacase Aktor Walikelas

Pada gambar 2 aktor walikelas berhak untuk mengelola data nilai siswa berdasarkan kelas yang diajar, data sikap siswa, data kesehatan siswa, data kriteria, data konversi kriteria dan fitur spk.

\subsubsection{Aktor Tata Usaha}

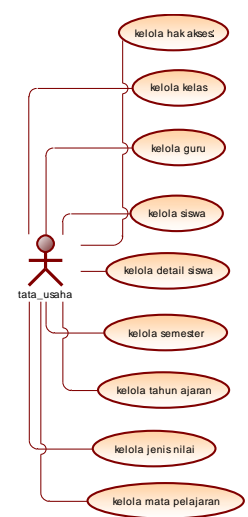

Gambar 3 Usecase Aktor Tata Usaha

Pada Gambar 3 aktor tata usaha berhak untuk mengelola data guru, data siswa, data kelas, data tahun ajaran, data jenis nilai, data semester, data detail siswa, data mata pelajaran, dan hak akses pengguna sistem.

\subsection{Pre-processing}

Sistem ini memiliki 4 kriteria yaitu sikap siswa, penggunaan kacamata, nilai siswa, tinggi badan siswa. Masing - masing kriteria memiliki konversi kriteria. Seperti sikap siswa memiliki konversi kriteria sangat baik, baik, perlu bimbingan. Untuk kriteria kacamata memiliki konversi kriteria memakai dan tidak memakai. Begitu juga untuk kriteria nilai siswa dan tinggi badan.

Pre-processing disini dilakukan hanya untuk konversi kriteria tinggi badan, dimana ada data acak yang telah dientri oleh walikelas ke dalam sistem, lalu sistem secara otomatis membuat interval interval kelas untuk konversi kriteria tinggi badan. Dengan menerapkan fungsi distribusi frekuensi kriteria tinggi badan memiliki konversi kriteria yang ditunjukkan pada tabel 3.2. 


\subsection{Alternatif dan Kriteria}

\subsubsection{Alternatif}

Alternatif yang digunakan pada sistem ini yaitu seluruh siswa dalam suatu kelas, dimana sampel yang diambil satu kelas dengan jumlah siswa sebanyak 30. Sistem akan memproses alternatif tiap satu kelas dengan pola posisi duduk sama dimana pola posisi duduk mengular yaitu alternatif rangking 1 duduk di posisi depan meja guru, rangking 2 duduk disebelah kiri rangking 1 , rangking 9 duduk dibelakang rangking 8 dan seterusnya.

\subsubsection{Kriteria}

Dari hasil wawancara dan observasi yang dilakukan dilapangan, didapatkan perancangan bobot untuk masing - masing kriteria. Bobot yang diberikan pada sistem pendukung keputusan rotasi posisi duduk siswa dalam kelas dilakukan secara dinamis tetapi jumlah dari semua kriteria harus 10 . Berikut daftar inputan bobot pada tabel.1

Tabel 1 Tabel Kriteria dan Bobot

\begin{tabular}{|c|l|c|}
\hline No. & \multicolumn{1}{|c|}{ Kriteria } & Input Bobot \\
\hline 1 & Sikap Siswa & 3 \\
\hline 2 & Penggunaan Kacamata & 3 \\
\hline 3 & Nilai Siswa & 2 \\
\hline 4 & Tinggi Badan Siswa & 2 \\
\hline
\end{tabular}

Setiap kriteria memiliki opsi dan nilai atau bisa disebut dengan konversi kriteria yaitu :

Tabel 2 Tabel Konversi Kriteria

\begin{tabular}{|c|c|c|c|}
\hline No & Kriteria & Konversi & Nilai \\
\hline \multirow[t]{3}{*}{1} & \multirow{2}{*}{$\begin{array}{l}\text { Sikap } \\
\text { Siswa }\end{array}$} & Sangat Baik & 1 \\
\hline & & Baik & 1.5 \\
\hline & & Perlu Bimbingan & 3 \\
\hline 2 & \multirow{2}{*}{$\begin{array}{l}\text { Penggunaan } \\
\text { Kacamata }\end{array}$} & Tidak Memakai & 1 \\
\hline & & Memakai & 3 \\
\hline \multirow[t]{10}{*}{3} & Nilai Siswa & 4 & 1 \\
\hline & & $3.66 \leq$ nilai $<4.00$ & 1.1 \\
\hline & & $3.33 \leq$ nilai $<3.66$ & 1.2 \\
\hline & & $3.00 \leq$ nilai $<3.33$ & 1.3 \\
\hline & & $2.66 \leq$ nilai $<3.00$ & 1.4 \\
\hline & & $2.33 \leq$ nilai $<2.66$ & 1.5 \\
\hline & & $2.00 \leq$ nilai $<2.33$ & 1.6 \\
\hline & & $1.66 \leq$ nilai $<2.00$ & 1.7 \\
\hline & & $1.33 \leq$ nilai $<1.66$ & 1.8 \\
\hline & & $0 \leq$ nilai $<1.33$ & 2 \\
\hline \multirow[t]{6}{*}{4} & \multirow{2}{*}{$\begin{array}{l}\text { Tinggi } \\
\text { Badan }\end{array}$} & $133-136$ & 1 \\
\hline & & $129-132$ & 1.2 \\
\hline & & $125-128$ & 1.4 \\
\hline & & $121-124$ & 1.6 \\
\hline & & $117-120$ & 1.8 \\
\hline & & $113-116$ & 2 \\
\hline
\end{tabular}

\section{Implementasi}

\subsection{Implementasi Basis Data}

Basis data yang diperlukan dalam sistem ini diberi nama 'rotasi_duduk' seperti pada gambar 4

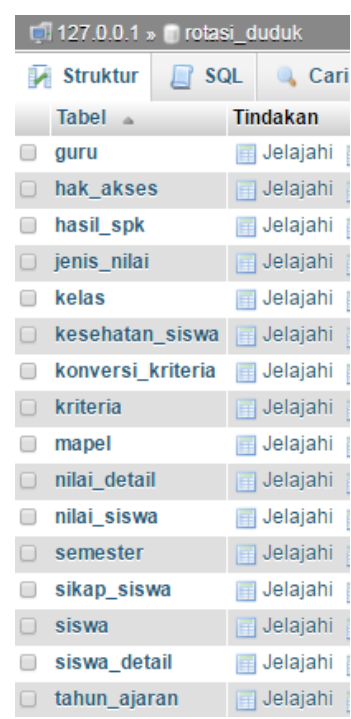

Gambar 4 Implementasi Basis Data

\subsection{Implementasi Antarmuka}

Perancangan yang telah dibuat, diimplementasikan ke dalam sistem pendukung keputusan ini. Halaman data siswa sesuai kelas walikelas mengajar dimana data siswa ini sebagai alternatif spk.

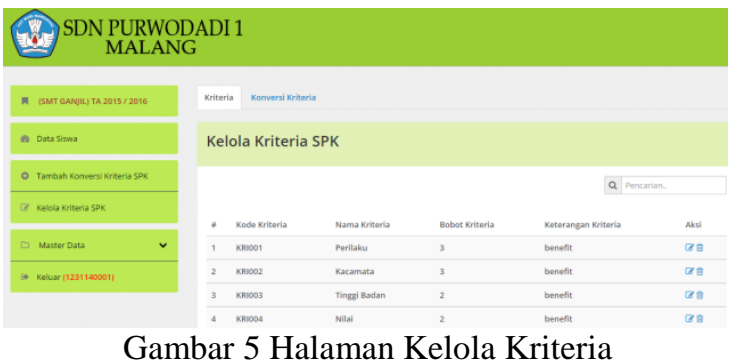

Pada gambar 5 menunjukkan kelola kriteria SPK dimana bobot tiap kriteria bisa diubah dengan jumlah ke 4 kriteria 10. Berikut implementasi hasil perangkingan spk menjadi pola posisi duduk siswa.

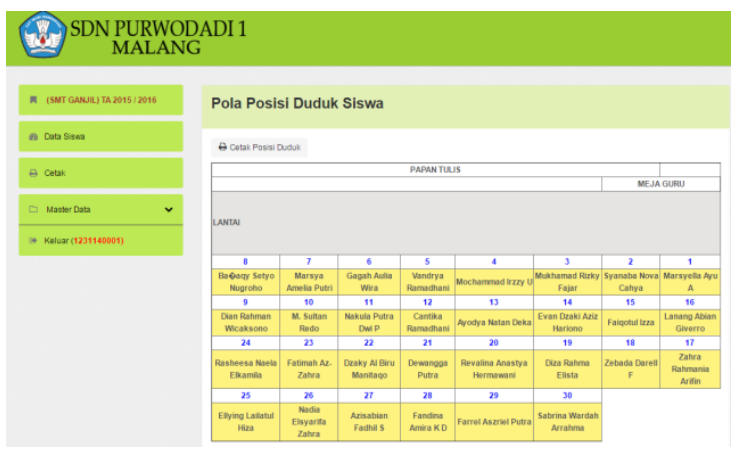

Gambar 6 Halaman Hasil Posisi Duduk Siswa

\section{Pengujian dan Pembahasan}

Pada pengujian ini terdapat tiga jenis uji coba yang akan ditampilkan yaitu pengujian fungsional, pengujian manual, pengujian hasil. 


\subsection{Pengujian}

\subsubsection{Pengujian Fungsional}

Digunakan untuk menguji fungsi-fungsi khusus dari perangkat lunak yang dirancang. Kebenaran perangkat lunak yang diuji hanya dilihat berdasarkan keluaran yang dihasilkan dari data atau kondisi masukan yang diberikan untuk fungsi yang ada tanpa melihat bagaimana proses untuk mendapatkan keluaran tersebut. Dari keluaran yang dihasilkan, kemampuan program dalam memenuhi kebutuhan pemakai dapat diukur sekaligus dapat diketahui kesalahan-kesalahannya. Menurut pengujian fungsional yang telah dilakukan, hasil yang didapatkan telah berjalan sesuai perencanaan.

\subsubsection{Pengujian Manual}

Tujuan dari pengujian manual adalah menjamin user yang berinteraksi dengan sistem terotomatisasi dapat melakukan fungsinya secara tepat. Pengujian ini dilakukan dengan cara menghitung ketepatan perhitungan metode dengan bantuan pendukung aplikasi Microsoft Excel. Hasil dari pengujian manual ini akan dicocokan dengan hasil pengujian sistem. Disimpulkan bahwa output dari hasil pengujian manual menunjukkan sistem (nilai SAW) sudah sama dengan hasil perhitungan manual dengan metode SAW. Diambil 5 sampel data dalam pengujian manual ini yang ditunjukkan pada tabel 5.1.

Tabel 3 Tabel Nilai Siswa

\begin{tabular}{|l|c|c|c|c|}
\hline \multirow{2}{*}{ Alternatif } & \multicolumn{4}{|c|}{ Kriteria } \\
\cline { 2 - 5 } & Sikap & Kacamata & Nilai & $\begin{array}{c}\text { Tinggi } \\
\text { Badan }\end{array}$ \\
\hline Dewangga & baik & tidak & 690 & 127 \\
\hline Farrel A. & baik & tidak & 709 & 133 \\
\hline Fatimah A & baik & tidak & 695 & 125 \\
\hline Syanaba & $\begin{array}{c}\text { Perlu } \\
\text { bim- } \\
\text { bingan }\end{array}$ & tidak & 643 & 119 \\
\hline Diza R. E. & baik & tidak & 774 & 128 \\
\hline
\end{tabular}

Nilai pada tabel diatas didapatkan dari entri data nilai masing - masing siswa. Setelah mendapatkan nilai siswa yang akan diolah, melanjutkan ke langkah berikutya yaitu matriks $\mathrm{X}$ perbandingan yang ditunjukkan tabel 4 .

\begin{tabular}{|l|c|c|c|c|}
\hline \multirow{2}{*}{ Alternatif } & \multicolumn{5}{c|}{ Kriteria } \\
\cline { 2 - 5 } & Sikap & Kacamata & Nilai & $\begin{array}{c}\text { Tinggi } \\
\text { Badan }\end{array}$ \\
\hline Dewangga & 1.5 & 1 & 1.6 & 1.4 \\
\hline Farrel & 1.5 & 1 & 1.6 & 1 \\
\hline Fatimah & 1.5 & 1 & 1.6 & 1.4 \\
\hline Syanaba & 3 & 1 & 1.5 & 1.8 \\
\hline Diza R. E. & 1.5 & 1 & 1.7 & 1.4 \\
\hline
\end{tabular}

Setalah melakukan pencocokan nilai yang ada dengan konversi kriteria didapatkan matrik $\mathrm{X}$ perbandingan. Selanjutnya dilakukan normalisasi metode SAW pada tabel 5.

Dimana perilaku, kacamata, nilai, dan tinggi termasuk kriteria benefit. Sehingga dicari nilai max dari semua data kriteria dari tabel matriks X. Dari hasil mencari nilai max dari masing - masing kriteria didapatkan pembaginya adalah : 3, 3, 1.7, 2. Berikut perhitungan manual normalisasi untuk 5 sampel data diatas :

Tabel 5 Perhitungan Manual Normalisasi

\begin{tabular}{|l|c|l|c|c|}
\hline \multirow{2}{*}{ Alternatif } & \multicolumn{4}{|c|}{ Kriteria } \\
\cline { 2 - 5 } & Sikap & Kacamata & Nilai & $\begin{array}{c}\text { Tinggi } \\
\text { Badan }\end{array}$ \\
\hline Dewangga & $\frac{1.5}{3}=$ & $\frac{1.5}{3}=0.33$ & $\frac{1.7}{2}=$ & $\frac{1.4}{2}=$ \\
& 0.5 & 0.944 & 0.7 \\
\hline \multirow{2}{*}{ Fatimah } & $\frac{1.5}{3}=$ & $\frac{1.5}{3}=0.33$ & $\frac{1.6}{1.7}=$ & $\frac{1.4}{2}=$ \\
& 0.5 & 0.944 & 0.7 \\
\hline Syanaba & $\frac{3}{3}=1$ & $\frac{1.5}{3}=0.33$ & $\frac{1.5}{1.7}=$ & $\frac{1.8}{2}=$ \\
0.88 & 0.9 \\
\hline Diza R. E. & $\frac{1.5}{3}=$ & $\frac{1.5}{3}=0.33$ & $\frac{1.7}{1.7}=1$ & $\frac{1.4}{2}=$ \\
0.7
\end{tabular}

Setelah didapatkan nilai normalisasi selanjutnya mencari nilai $\mathrm{V}$ untuk mendapatkan hasil akhir yang nantinya digunakan sebagai perangkingan dengan cara jumlah dari perkalian bobot kriteria dengan matrik normalisasi ditunjukkan di tabel 5.4. Bobot masing - masing yaitu $3,3,2,2$.

Tabel 6 Pengujian Manual Nilai V

\begin{tabular}{|l|c|c|}
\hline Alternatif & Perhitungan & Nilai V \\
\hline Dewangga & $(0.5 * 3)+(0.33 * 3)+(0.944 * 2)+(0.7 * 2)$ & 5.788 \\
\hline Farrel & $(0.5 * 3)+(0.33 * 3)+(0.944 * 2)+(0.5 * 2)$ & 5.388 \\
\hline Fatimah & $(0.5 * 3)+(0.33 * 3)+(0.944 * 2)+(0.7 * 2)$ & 5.788 \\
\hline Syanaba & $(1 * 3)+(0.33 * 3)+\left(0.88^{*} 2\right)+(0.9 * 2)$ & 7.564 \\
\hline Diza R.E. & $(0.5 * 3)+(0.33 * 3)+(1 * 2)+(0.7 * 2)$ & 5.9 \\
\hline
\end{tabular}

Setelah didapatkan nilai $\mathrm{V}$ dari 30 data, selanjutnya dilakukan perangkingan dari nilai terkecil sampai terbesar ditunjukkan pada tabel 7 .

Tabel 7 Rangking Alternatif

\begin{tabular}{|c|l|c|}
\hline Rangking & \multicolumn{1}{|c|}{ Alternatif } & Nilai V \\
\hline 1 & Marsyella Ayu A & 7.764706 \\
\hline 2 & Syanaba Nova Cahya & 7.564706 \\
\hline 3 & Mukhamad Rizky F. & 7.482353 \\
\hline 4 & Mochammad Irzzy U & 7.464706 \\
\hline 5 & Vandrya Ramadhani & 7.382353 \\
\hline
\end{tabular}

Hasil rangking ini didapatkan dari pengurutan nilai $\mathrm{V}$ dari terkecil ke terbesar. Perangkingan ini yang digunakan sebagai acuan posisi duduk siswa dalam kelas yang akan diimplementasikan pada pola posisi duduk yang ada dikelas. Alternatif yang 
memiliki nilai rendah akan diposisikan duduk di depan dan sebaliknya.

\subsubsection{Pengujian Hasil}

Sistem akan melakukan fungsi - fungsinya untuk menghasilkan langkah - langkah metode SAW dan hasilnya didapatkan hasil uruta perangkingan siswa.

\subsection{Pembahasan}

Pada halaman ini, perangkingan SPK diambil dari nilai terbesar hingga terkecil. Rangking pertama atau siswa dengan nilai terbesar akan menempati posisi duduk di depan meja guru dan seterusnya dengan posisi duduk mengular. Rangking ditunjukkan pada gambar 7

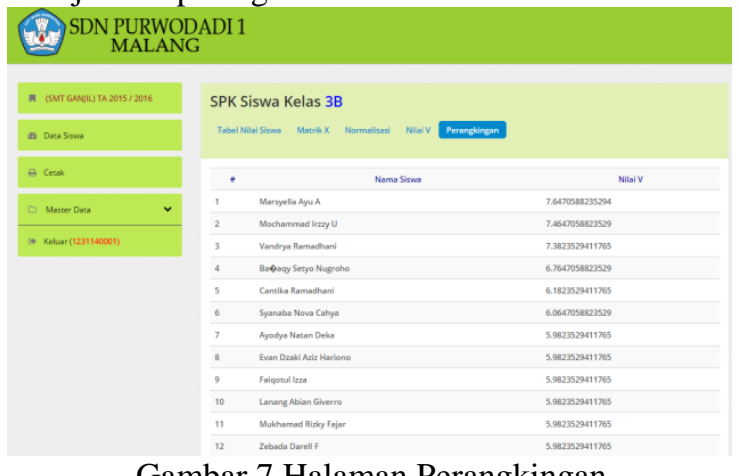

Gambar 7 Halaman Perangkingan

Pola posisi duduk ini berdasarkan perangkingan yang dihitung dengan metode SAW. Rangking 1 duduk di posisi depan meja guru, rangking ke 2 duduk disebelah rangking 1, rangking 9 duduk dibelakang rangking 8 . Rangking 17 duduk dibelakang rangking 16 . Rangking 25 duduk dibelakang rangking 24 .

Berikut gambar 8 halaman hasil pola posisi duduk siswa pada sistem.

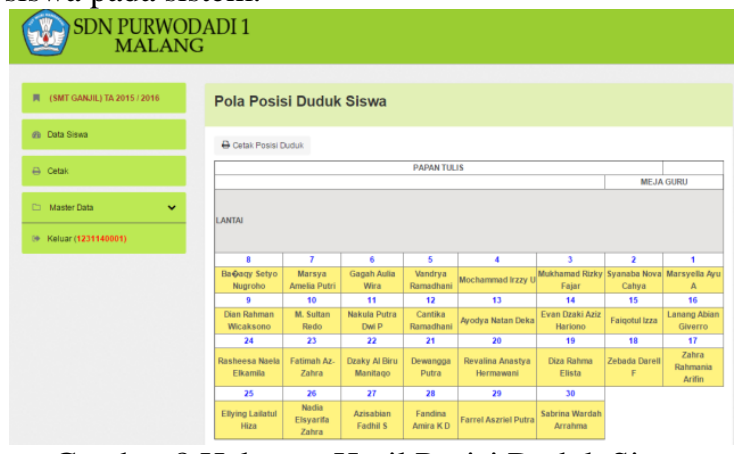

Gambar 8 Halaman Hasil Posisi Duduk Siswa

\section{Kesimpulan dan Saran}

\subsection{Kesimpulan}

Dari hasil pembuatan Sistem Pendukung Keputusan Rotasi Posisi Duduk Siswa Dalam Kelas (Studi Kasus SDN Purwodadi 1 Malang) dapat diambil kesimpulan berikut :
2. Sistem Pendukung keputusan rotasi posisi duduk siswa dalam kelas ini dapat memberikan penilaian pendukung keputusan rotasi posisi duduk siswa dalam kelas dengan menggunakan metode SAW berupa rangking dan selanjutnya diimplementasikan pada pola posisi duduk siswa.

3. Sistem pendukung keputusan rotasi posisi duduk siswa dalam kelas dapat membantu walikelas untuk mendukung keputusan rotasi posisi duduk siswa dalam kelas berdasarkan empat kriteria yaitu sikap siswa, penggunaan kacamata pada siswa, nilai siswa dan tinggi badan siswa terbukti berdasarkan hasil kuesioner yang diisi oleh walikelas dengan tingkat akurasi sebesar $82 \%$.

\subsection{Saran}

Adapun saran untuk meningkatkan kinerja dan penyempurnaan sistem pendukung keputusan yang telah dibuat :

1. Sistem pendukung keputusan rotasi posisi duduk siswa dalam kelas ini bisa menggunakan dengan metode - metode lainnya yang dapat menghasilkan perangkingan, seperti TOPSIS, ELECTRE sehingga dapat dilakukan perbandingan hasil nilai dari metode SAW dengan metode lainnya.

2. Sistem pendukung keputusan rotasi posisi duduk siswa ini dapat ditambahkan kriteria lainnya seperti berat badan siswa, jenis kelamin, dll sehingga menghasilkan nilai yang lebih kompleks.

\section{Daftar Pustaka}

Ariyanto, Rudy. 2013. "Sistem Pendukung Keputusan Kelompok Untuk Seleksi Proposal Penelitian Hibah Bersaing Menggunakan Metode FAHP dan FMCDM (Studi Kasus: UPT P2M Politeknik Negeri Malang)". Tesis Program Studi S2 Ilmu Komputer Fakultas Matematika Dan Ilmu Pengetahuan Alam Universitas Gadjah Mada Yogyakarta” All GDSS PHB V.41 (Desember 2013)

Dr. Sudaryono. 2015. "Metodologi Riset di Bidang IT (Panduan Praktis, Teori, dan Contoh Kasus)". Andi : Yogyakarta

Drs.Riduwan, M.B.A. 2005. "Dasar - Dasar Statistika". Alfabeta : Bandung

Drs. Syaiful Bahri Djamarah, M.Ag. dan Drs. Aswan Zain. 2013. "Strategi Belajar Mengajar”. Rineka Cipta : Jakarta

Irfan Subakti. 2002. "IFI1524 Sistem Pendukung Keputusan (Decision Support System).directory.umm.ac.id/tik/Buku_Pandua n_SPK.pdf'. Jurusan Teknik Informatika Fakultas Teknologi Informasi. Institut Teknologi Sepuluh November Surabaya. Diakses 7 November 2015 
Jasin.Anwar. 1996. "Pengelolaan Kelas". PT. Gramedia Widiasrana Indonesia : Jakarta

Kusrini, M.Kom, 2007. "Konsep dan Aplikasi Sistem Pendukung Keputusan”. Andi : Yogyakarta.

Mansyur Thalib, Muhammad.2014. "Pengaruh Pemberian Tugas dan Posisi Tempat Duduk Terhadap Hasil Belajar Statistik Pendidikan", http://jurnal.untad.ac.id/jurnal/index.php/Kreati f/article/view/2397

Sidik, Rohman. Maret 2014. "Sistem Pendukung Keputusan Dalam Menentukan Kelayakan Lokasi Untuk Membangun Tower Pemancar Sinyal Menggunakan Metode Simple Additive Weighting $(S A W) "$. Jurnal Pelita Informatika Budi Darma, Volume : VI, Nomor 1, Maret 2014 ISSN : 2301-9425, https://docs.google.com/uc?export=download\& id=0B0kHciMbdcXNM3F4d09palJSZIE

Turban, Efrain, Dkk. 2005. "Decision Support System and Intelligent Systems (Sistem Pendukung Keputusan dan Sistem Cerdas) Edisi 7 Jilid 1". Andi : Yogyakarta

Usito, Nugroho Joko. 2013. "Sistem Pendukung Keputusan Penilaian Proses Belajar Mengajar Menggunakan Metode Simple Additive Weighting $(S A W)^{\prime}$. Tesis Program Magister Sistem Informasi Pascasarjana Univeristas Diponegoro Semarang, http://core.ac.uk/download/pdf/18605548.pdf

Valensia, Verina, dkk. 2012. "Aplikasi Tutorial Sistem Pendukung Keputusan Menggunakan Metode Simple Additive Weighting”. Jurnal Teknik Informatika Vol 1 September 2012. Program Studi Teknik Informatika Politeknik Caltex Riau, http://aksara.pcr.ac.id/page/read_pdf.php?na e=jurnal-verina-baru_-revisi1.pdf\&id=60, 1 September 2012 